\title{
EDITORIAL
}

\section{PREVENTION OF OCCUPATIONAL DEAFNESS}

\author{
"We are the boys \\ That fear no noise \\ Where the thundering cannons roar". \\ Oliver Goldsmith 1773
}

Goldsmith's words epitomize an attitude still unfortunately prevalent throughout the Army. Soldiers may yet be found who consider hearing protection to be another symptom of what is thought of as today's over-protective mollycoddling and effeminate philosophy. Old soldiers often hark back sadly to the "good old days" - fortunately now long past - when it was considered manly to defy human physiology; to hold one's drink, to march without water and to withstand the noise of gunfire. No hearing conservation prognamme can be comprehensive or effective unless it is succesful in convincing its hearers, while they can still hear, of the insidious, irreversible and inevitable nalture of the noise induced deafness which will follow unprotected exposure to the Army's modern weapons. The cannons' roar at Blenheim, Waterloo or Sebastopol probably damaged the hearing of the gunners but the damage was miniscule in extent when compared with that caused by contemporary weapons. Today the infantry soldier, more so than the artilleryman, is at risk from impulsive noise. Rifle and anti-tank weapons are particular hazards: as their lethality and effectiveness has improved so has their potential for harm to the firer. They are two-edged weapons in more than a merely metaphorical sense.

An axiom of occupational medicine, stemming from identification of a health hazard, is the abolition or substitution of the culpable agent. For the Army's weapons such a course is clearly impracticable, but it is to be hoped that new weapons can be made less hazardous to the firer at the same time as they are made more hazardous to the target. Would that even a tithe of the sums spent on research and development into enhanced destructiveness could be diverted towards reducing the risks of deafening the soldier at the firing point.

Deafness is an occupational disease of soldiering. Specifically military causes are in descending order of magnitude, the impulsive noise generated by small arms fire, other weapon systems, and the continuous noise of armoured fighting vehicles and aircraft. The problem is being tackled energetically, but more action is needed along the lines suggested above - more widespread awareness of the risk and more thought to the production of quieter weapons and equipment.

The Army hearing conservation programme has now been started in earnest but none itoo soon. Since 1970 the Royal Air Force has had an active programme in operation, a model of practical protection ${ }^{1}$. In that the major risk comes from impulsive noise, the Army's problem is both larger in scope and more comprehensive in nature. The measurement of noise intensity and, where dangerous, its reduction are cardinal aims of the programme. Inevitably progress in these directions is 
limited and the programme necessarily concentrates on personal protection and audiometric monitoring. Whereas the V51 R personal ear plugs remain the standdard protective for all soldiers, research is continuing to find better and more convenient methods. But hearing protection is no use unless used and a major step forward will have been achieved when the wearing of ear plugs becomes accepted and universal. Much prejudice and superstition has still to be overcome.

Screening audiomeltry is now prescribed for every recruit, and shortly to commence is a programme of routine audiometry to a periodicity linked to the degree of exposure and risk. Those found to have signs of noise induced hearing loss, customarily occurring first at the higher frequencies and only later in the speech bands, must be protected from further damage if subsequent social hearing damage is to be avoided. Already the extent of early deafness among officers and soldiers, sufficient to cause downgrading under the $H$ quality of the PULHEEMS system, is the source of concern. As well as ensuring that deafened individuals are removed from further hazard there is need to reassess required sitandards of hearing for a multitude of military tasks where acute auditory perception is not a prerequisite. Thus many may be usefully employed who otherwise might be made redundant by the application of unnecessarily stringent standards.

One thing is certain and that is the Army's otologists will be busily employed in the coming years. Military deafness is no new phenomenon as readers may discover elsewhere in this issue ( $p$ 171) but the recruitment of extra otologists may not be as straightforward as suggested by Cottell in $1910^{2}$.

In conclusion, in the piping days of peace, noise induced deafness is a preventable condition. In wartime the circumstances would differ but right now the Medical Services must find an effective answer to the question "if preventable, why not prevented?”.

\section{REFERENCES}

1. KING, P F (1978). Hearing conservation in the Royal Air Force. Journal of the Royal Society of Medicine 71, 562-573.

2. Cottell, R C (1910). A plea for the employment of aurists in connection with recruiting. Journal of the Royal Army Medical Corps 14, 549-550.

\section{JOURNAL STYLE}

With this third and last number of Volume 125 there comes to an end the period of grace allowed to authors, presaged in the first issue of this volume ${ }^{1}$, as regards the style of their manuscripts. The notice to authors should now be complied with by all potential contributors; papers which do not fulfil the revised requirements will not be rejected on that account, but they are likely to be delayed by the need for editorial rearrangement and amendment.

Observant readers of other medical journals will note that the majority now follow the lead set by the International Steering Committee of Medical Editors ${ }^{2,3}$ and ask for manuscripts to be submitted in accordance with the Vancouver Declaration. This Journal, albeit slowly, follows suit. An impediment to full implementa- 
tion is the absence of an officially abbreviated title. The new agreement requires editors to use the forms of abbreviation adopted by Index Medicus. Unfortunately the Journal of the Royal Army Medical Corps is not included in the list of Journals cited by Index Medicus. Until such time as this anomaly is put right this Journal has no alternative but to adhere to uniformity in reference lists by asking that titles are spelled out in full.

\section{REFERENCES}

1. Editorial (1979). The Health of the Journal. Journal of the Royal Army Medical Corps 125, 2-3.

2. International Steering Committee of Medical Editors (1979). Uniform requirements for manuscripts submitted to bio medical journals. British Medical Journal 1, 532-535.

3. Editorial (1978). Towards a common style. Lancet 2, 1242.

\section{BIRTHDAY HONOURS LIST 1979} 1979:

The following awards were published in the London Gazette on 16 June

C.B.

Brig. J. O. E. MORIARTY, Q.H.N.S., R.R.C., Q.A.R.A.N.C.

C.B.E. $\quad$ Brig. R. H. Freeman, M.B., Ch.B., F.R.C.S., L.R.C.P.

O.B.E. Maj. (A/Lt. Col.) W. J. D. BRadfield, M.C., T.D., M.B., B.S., F.R.C.S., R.A.M.C., T.A.V.R.

B.E.M. S/Sgt. C. Jones, R.A.M.C.

R.R.C. $\quad$ Lt. Col. M. BuCHANAN, Q.A.R.A.N.C., T.A.V.R.

Lt. Col. V. J. SMITH, Q.A.R.A.N.C.

Lt. Col. G. A. Staines, Q.A.R.A.N.C.

Lt. Col. (Rtd) A. G. WILLIAMS, Q.A.R.A.N.C.

A.R.R.C. Maj. J. M. ARIGHo, Q.A.R.A.N.C.

Maj. M. J. Clune, Q.A.R.A.N.C.

Maj. J. M. FIELD, Q.A.R.A.N.C.

Maj. B. D. TANSLAY, Q.A.R.A.N.C.

Capt. R. TATE, R.A.M.C. 